УДК 378.016:811

DOI:

Віта Безлюдна, доктор педагогічних наук, доцент кафедри іноземних мов Уманського державного педагогічного університету імені Павла Тичини

\title{
МЕТОДИКА ВИКЛАДАННЯ ІНОЗЕМНИХ МОВ У ВИЩИХ НАВЧАЛЬНИХ ЗАКЛАДАХ: ІСТОРІЯ ТА СУЧАСНІСТЬ
}

У статті зроблено спробу проаналізувати історію розвитку методики викладання іноземних мов у вищих навчальних закладах Украйни з початку 50-х років ХХ століття і донині. Наголошено, що методика викладання іноземних мов змінювалася $і$ визначалася цілями $i$ завданнями розвитку держави. Розглянуто основні підходи і методики викладання іноземних мов у вищій школі у означений період. Встановлено, щзо забезпечення високого рівня методики викладання іноземних мов у закладах вищої освіти можливо за умови використання викладачами методів, підходів $і$ методик, щзо відповідають завданням сучасності $і$ поєднують в собі найкраще, що було створено багатьма поколіннями методистів і викладачів.

Ключові слова: методика; іноземні мови; вища освіта; студенти.

Jim. 9.

Vita Bezlyudna, Doctor of Sciences (Pedagogy), Associate Professor of the Foreign Languages Department of Uman State Pedagogical University

\section{METHODOLOGY OF TEACHING FOREIGN LANGUAGES IN HIGHER EDUCATIONAL INSTITUTIONS: HISTORY AND MODERNIZATION}

The article presents an analysis of history of the methodology development of teaching foreign languages in higher educational institutions of Ukraine since the early 50's of the twentieth century and up to modern period. It was emphasized that the methodology of teaching foreign languages was changed and determined by the goals and objectives of the state development. The main approaches and methods of teaching foreign languages at higher education in the specified period are considered.

The author identified that in 60-ies of the twentieth century dominated consciously-comparable and consciously-practical methods, these years are characterized by an increase in the cognitive-activity component in the teaching of foreign languages in higher educational institutions; formation of communicative and intensive approaches. In the 70-ies and 80-ies the practical orientation of teaching methods of foreign languages is emphasized, in the requirements of methodologists is stated the necessity of formation of linguistic and national knowledge and skills. Foreign language gives students access to the culture of other countries, providing in the learning process a "dialogue of cultures". In the 90-ies of the twentieth century intensified attention to methodological training, which was considered a system-based factor in the training of the future foreign languages teacher. At the same time, it is a relatively independent system with its own content, structure and functions. It is provided by studying the cycle of educational disciplines (teaching methods of foreign languages), special courses and special seminars.

It is noted that today the improvement of the methodology of learning a foreign language is seen in its optimization based on the principles of competence, activity and communication approaches, in the development of effective education models based on system research, the application of modern teaching methods, the use of problem methods, the use of information and telecommunication technologies etc.

It was established that the provision of a high level of teaching methods of foreign languages in higher education institutions is possible only if teachers use methods, approaches and techniques that are in line with the tasks of the present and combine the best that has been created by many generations of methodologists and teachers.

Keywords: methodology; foreign languages; higher education; students.

П остановка проблеми. Викладанню іноземних мов у вузах України завжди приділялася велика увага. Із початком XIX століття історія вищої освіти в Україні, зокрема й педагогічної, тісно пов'язана 3 університетами, котрі, маючи у своєму складі училищні комітети, протягом тривалого часу визначали напрями діяльності всіх навчальних закладів в освітньому окрузі, до якого належали.
В школах, гімназіях, університетах викладалися такі іноземні мови як латинська, французька, німецька, грецька та ін. Методика викладання іноземних мов змінювалася і визначалася цілями і завданнями розвитку держави.

В історії нашої країни був період, коли вивчення іноземних мов мало другорядний, непріоритетний характер і фахівці, які не знали іноземної мови протиставлялися фахівцям, для яких іноземна 


\section{МЕТОДИКА ВИКЛАДАННЯІНОЗЕМНИХ МОВ У ВИЩИХ НАВЧАЛЬНИХ ЗАКЛАДАХ: ICTOРІЯ ТАСУЧАСНICТЬ}

мова була, безпосередньо, спеціальністю. Наприклад, у першій половині XX століття соціально-економічна ситуація не вимагала від випускників вузів глибоких знань з іноземної мови. Однак, навіть при постановці такого завдання, їі виконання було б досить проблематичним у післявоєнні роки через відсутність системи вивчення іноземних мов у середній школі. Система вищої освіти відчувала гострий дефіцит ресурсів - матеріальних, кадрових, дисциплінарних тощо. [5, $201-207]$.

Аналіз основних досліджень і публікацій. Теоретичні і практичні аспекти проблеми викладання іноземних мов у вищій школі завжди були в центрі наукового пошуку провідних фахівців у галузі історії педагогіки. Розвитку теорії і практики іншомовної освіти присвячено наукові розвідки В. Андрієвської, С. Ніколаєвої, С. Пасова, 3. Цвєткової та ін. Історико-педагогічний аналіз іншомовної підготовки вчителів виконано А. Долапчі, Б. Лабінською, О. Мисечко, І. Соколовою, О. Шмирко та ін. Сучасний стан методики викладання іноземних мов вивчають О. Бігич, С. Тер-Минасова, М. Скуратівська, Я. Черньонков та ін.

Мета статті - зробити історичний аналіз розвитку методики викладання іноземних мов у вищих навчальних закладах України 3 початку 50-х років XX століття і донині.

Виклад основного матеріалу. На думку О. Сухомлинської, початок 50-х рр. -60-ті pp. XX століття, принесли нові тенденції й якісні зміни у розвиток радянської освіти. Вища освіта була всередині цих змін і також почала трансформуватися і реформуватися $[8,18]$.

21 вересня 1955 року Міністерство вищої освіти СРСР видало наказ “Про поліпшення викладання іноземних мов у вищих навчальних закладах" [4]. Виходячи з наявних недоліків у викладанні іноземних мов у вузах було наказано запровадити в усіх немовних вузах викладання іноземних мов 3 I - IV курси. Перед викладачами кафедр ставили завдання подальшого підвищення рівня навчальної та методичної роботи, щоб по завершенню IV-го курсу студенти могли вільно користуватися спеціальною літературою на іноземній мові.

У 60-ті роки політика держави починає змінюватися, міжнародні зв'язки СРСР розширюються. 27 травня 1961 рокубуло прийнято Постанову Ради Міністрів СРСР № 468 "Про поліпшення вивчення іноземних мов”, в якій вказувалося на зростаюче значення знання іноземних мов фахівцями різних галузей науки. А саме "Міністерству вищої і середньої спеціальної освіти СРСР в 2-місячний термін пропонувалося внести зміни до навчальних планів університетів, в першу чергу з гуманітарних спеціальностей, 3 тим, щоб особи, які закінчують їх, вільно володіли іноземною мовою; усунути елементи лібералізму, наявні в практиці оцінки знань студентів 3 іноземних мов; вжити заходів до широкого розгортання в вищих навчальних закладах позааудиторної роботи, що сприяє підняттю рівня знань студентів 3 іноземних мов", крім цього встановлювалося кількість студентів в групах 12 - 15 осіб. На жаль, особливе ставлення до гуманітарних спеціальностей спочатку збільшувало розрив у рівні володіння іноземними мовами випускниками гуманітарних і педагогічних вузів, який згодом почав скорочуватися тільки в XXI столітті. У 60 роках XX століття випускник педагогічного вузу повинен був в змозі прочитати спеціальну літературу (зі словниковим запасом в тисячі слів), але не міг спілкуватися на побутовому рівні (словниковий запас всього кілька сотень слів). У 60 роках XX століття в методиці викладання іноземних мов панували свідомо-зіставна і свідомо-практична методики [5, 286].

Водночас ці роки характеризуються посиленням когнітивно-діяльнісної складової у викладанні іноземних мов у вузах: виокремлюється країнознавчий аспект як форма інтеграції спецдисциплін у змісті навчання мови; формується комунікативний підхід; інтенсивний підхід (розкриття резервів пам'яті, інтелектуальної активності й особистості та ін.); впроваджується метод активізації можливостей особистості й колективу (оволодіння комплексом навичок і вмінь для майбутньої мовної діяльності); підвищувався інтерес до проблеми самостійної роботи (розширення професійних знань засобами мови на основі високоінформативних текстів і системи вправ) тощо [2, 114].

Прихильники свідомо-порівняльної методики розробляють моделі і мовні одиниці, розвивають систему навчання усного мовлення. Граматичне правило стає алгоритмом дії в практичній ситуації, використання правил стає більш гнучким. Було порушено проблему інтерференції рідної мови. Студенти повинні були зрозуміти в процесі навчання, що способи вираження однієї думки рідною та іноземною мовами різні. Адепти свідомо-практичного методу ставлять собі за мету створення загальної концепції, заснованої на єдиних принципах [5, $287-288]$ : мовної спрямованості і ситуативності, комплексного навчання усіх видів мовної діяльності, співвіднесення з рідною мовою, взаємодоповнення 


\section{МЕТОДИКА ВИКЛАДАННЯІНОЗЕМНИХ МОВ У ВИЩИХ НАВЧАЛЬНИХ ЗАКЛАДАХ: ICТОРІЯТАСУЧАСНІСТЬ}

довільного і мимовільного (сьогодні це основа компенсаторної компетенції), принцип перенесення мовних дій на нові умови.

Ці методичні підходи лягли в основу методики навчання іноземних мов у середній школі та у вищих лінгвістичних навчальних закладах в 70-ті роки XX століття і дещо пізніше починають застосовуватися в немовних вузах.

У 70-ті і 80-ті роки підкреслюється практична спрямованість методик викладання іноземних мов, у вимогах методистів констатується необхідність формування лінгвокраїнознавчих знань і умінь. Іноземна мова дає студентам доступ до культури інших народів, забезпечуючи в процесі навчання “діалог культур” [3].

Після падіння “залізної завіси”, переходу від індустріального суспільства до інформаційного вивчення іноземних мов із затеорезованої дисципліни перетворюється у практичну необхідність. Протягом довгого часу процес утворення був орієнтований на диференціацію знань, а в умовах інформаційного суспільства для ефективного навчання студентів, інтегрується у знання, але зі збереженням і диференціації. Вищі заклади освіти потребують висококваліфікованих вузькопрофільних фахівців, але неізольованих від інших суміжних галузей знань, а здатних сприймати нові ідеї в процесі комунікації, в тому числі і з фахівцями, що володіють іноземними мовами. Як зазначає С. Тер-Минасова [9, 31], їх не цікавить ні теорія, ні історія мови, а іноземні мови, в першу чергу англійська, яка є необхідною для використання у різних сферах життя суспільства як засіб комунікації із фахівцями інших країн.

Так, у 90-х рр. ХХ століття посилилась увага до методичної підготовки, яка вважалася системотвірним чинником професійної підготовки майбутнього вчителя іноземних мов. Разом із тим, це відносно самостійна система 3 власним змістом, структурою, функціями. Вона забезпечується вивченням циклу навчальних дисциплін (методики викладання іноземних мов), спецкурсів і спецсемінарів; участю студентів у науково-дослідній і науково-методичній роботі та педагогічній практиці $[1,12]$.

Слід зауважити, що підготовка вчителя іноземної мови у ці роки передбачає теоретиколінгвістичну, практично-мовну, теоретичну, практичну психолого-педагогічну та теоретикометодичну підготовку $[6,10]$.

Зокрема, теоретико-методична підготовка передбачає забезпечення знань 3 теорії та методики навчання іноземних мов; навчання методичних основ організації навчально-виховного процесу 3 іноземних мов у різних типах загальноосвітніх навчальних закладів; формування вмінь самостійного методичного дослідження. Вчитель іноземної мови "має вміло застосовувати різноманітні методи, прийоми, форми навчання і сучасні технологічні засоби для навчання чотирьох видів іншомовної мовленнєвої діяльності в різних типах навчальних закладів, аналізувати зміст навчального матеріалу; прогнозувати труднощі засвоєння студентами мовленнєвого матеріалу 3 урахуванням особливостей як студента, так і певного навчального закладу; вирішувати задачі морального, культурно-естетичного, гуманістичного виховання студента засобами іноземної мови; планувати навчально-комунікативну діяльність студентів на заняттях; творчо розв'язувати методичні задачі в процесі навчання і виховання 3 урахуванням індивідуальних характеристик учнів" $[6,15]$.

Отже, гуманістична педагогіка, сконцентрована на людині, культурі і соціумі як взаємопов'язаних детермінантах освіти, спрямована на підтримку процесів індивідуального саморозвитку i самовизначення особистості стає основою навчання іноземних мов у вищих навчальних закладах.

Початок XXI століття характерний для нашої держави потребою у висококваліфікованих спеціалістах, здатних до встановлення ділових контактів та ділового співробітництва 3 іноземними партнерами, спеціалістах, що володіють іноземними мовами, особливо англійською, на фаховому рівні, знаходять відображення в робочих навчальних програмах закладів вищої освіти (ЗВО) країни. Іноземні мови стають не просто частиною культури певної нації, але і запорукою успіху майбутньої вдалої кар'єри студентів. Досягнення високого рівня володіння іноземною мовою не можливе без фундаментальної іншомовної підготовки у вищій школі. В більшості 3ВО студенти опановують принаймні дві іноземні мови.

Метою навчання іноземної мови в вищій школі стає оволодіння студентами комунікативними компетенціями, що дозволять реалізувати їхні знання, уміння, навички для розв'язання конкретних комунікативних завдань в реальних життєвих ситуаціях. Іноземна мова виступає як засіб комунікації, спілкування з представниками інших націй, отже в освіті продовжує розвиватися культурологічний підхід у навчанні в рамках концепції “діалогу культур”, з метою формування полімовної грамотності студентів [7].

Сьогодні удосконалення методики навчання 


\section{МЕТОДИКА ВИКЛАДАННЯ ІНОЗЕМНИХ МОВ У ВИЩИХ НАВЧАЛЬНИХ ЗАКЛАДАХ: ІСТОРІЯТАСУЧАСНІСТЬ}

іноземної мови бачиться в її оптимізації на основі принципів компетентнісного, діяльнісного і комунікативного підходів, в розробці ефективних моделей навчання, заснованих на системних дослідженнях, застосуванні сучасних методів навчання, залучення студентів до проектної діяльності, використання проблемних методів, застосування інформаційних та телекомунікаційних технологій (робота з навчальними комп'ютерними програмами 3 іноземних мов (система мультимедіа), дистанційні технології в навчанні іноземних мов, створення презентацій в програмі Power Point, використання інтернет-ресурсів, навчання іноземної мови в комп'ютерному середовищі (форуми, блоги, електронна пошта), мовного портфоліо, технології диференційованого навчання тощо) у формуванні цілей і змісту навчання в рамках гуманістичної педагогіки, в розробці системи контролю результатів, яка мотивує студентів до самовдосконалення i самостійної роботи над рівнем володіння іноземною мовою і після закінчення закладу вищої освіти.

Сучасне суспільство висуває до фахівця будьякого профілю високі вимоги, серед яких, комп'ютерна грамотність і знання іноземних мов є обов' язковими. Енциклопедичні знання відходять на другий план, а здатність застосовувати знання, вміння і навички роботи з інформацією, у тому числі і на іноземній мові, для вирішення поставлених завдань стають первинними для усіх громадян інформаційного суспільства. Процес вивчення іноземних мов, при використанні сучасних педагогічних технологій, володіє високим освітнім і виховним потенціалом, що сприяє становленню конкурентоспроможних професіоналів.

Висновки та перспективи подальших досліджень. Таким чином, сучасний етап характеризується соціальним замовленням громадян України на якісне володіння іноземними мовами, який відзначають такі чітко позначені тенденції іншомовної освіти, як: зростання статусу іноземної мови, посилення мотивації її вивчення, функціональна спрямованість навчання мовам. Зростаючий статус іноземної мови в сучасних умовах збільшує потребу в кваліфікованих учителях цієї дисципліни, обумовлюючи необхідність модернізації їх методичної підготовки в цілісній системі вищої лінгвістичної освіти. Однак вирішити завдання забезпечення високого рівня методики викладання іноземних мов у закладах вищої освіти можна тільки за умови використання викладачами методів, підходів і методик, що відповідають завданням сучасності і поєднують в собі найкраще, що було створено багатьма поколіннями методистів і викладачів. Тому перспективи подальших досліджень вбачаємо у виявленні перспективних шляхів вдосконалення методики викладання іноземних мов у закладах вищої освіти України на основі вивчення досвіду зарубіжних країнах.

\section{ЛІТЕРАТУРА}

1. Безлюдна В. В. Законодавчий аспект розвитку іншомовної освіти у ВПНЗ України (кінець 90-х рр. ХХ - початок XXI століття) / В. В. Безлюдна // Вісник Чернігівського національного педагогічного університету імені Т. Г. Шевченка. Чернігів: ЧНПУ, 2016. - Вип. 141. - С. 11-15 (Серія: "Педагогічні науки").

2. Безлюдна В.В.Професійна підготовка майбугніх учителів іноземних мов у вищих педагогічних навчальних закладах України (1948-2016 рр.): теорія і практика [Текст] : монографія / Віта Безлюдна; Уман. держ. пед. ун-т ім. Павла Тичини. - Умань: Сочинський [вид.], 2017. $-342 \mathrm{c.}$

3. Бім І. Л. Навчання іноземним мовам - пошук нових шляхів // ИЯШ, 1989, №1.

4. Высшая школа: сборник основных постановлений, приказов и инструкций: в 2-х ч. / под ред. Е. И. Войленко. М.: Высшая школа, 1978. - Ч. 2. -360 с.

5. Миролюбов А. А. История отечественной методики обучения иностранным языкам. - М. СТУПЕНИ, ИНФРА-М, 2002. - 448 c.

6. Ніколаєва С. Ю. Ступенева система освіти в Україні та система навчання іноземних мов / С. Ю. Ніколаєва, О. П. Петращук, Н. О. Бражник. - К.: Ленвіт, 1996. - 90 с.

7. Скуратівська М. О. Сучасні методи та технології викладання іноземних мов у віщій школі України / М.О. Скуратівська // Філологія та методика викладання: наук.-метод. вісник. - К.: Університет економіки та права “КРОК”, 2009. - C. 151-164.

8. Сухомлинська О. В. Радянська педагогіка як ідеологія: спроба історичної реконструкції / О.В.Сухомлинська // Історико-педагогічний альманах. 2014. - № 1. - C. 4-24

9. Тер-Минасова С. Г. Язык и межкультурная коммуникация. - 2-е издание, доработанное. - М.: Издво МГУ, 2004. $-352 \mathrm{c}$

\section{REFERENCES}

1. Bezlyudna, V. V. (2016). Zakonodavchyy aspekt rozvytku inshomovnoyi osvity u VPNZ Ukrayiny (kinets 90-kh rr. XX stolittya - pochatok XXI stolittya) [Legislative aspect of foreign language education at higher educational establishments of Ukraine (the end of 90-ies XX - the beginning of the XXI century)]. Bulletin of Taras Shevchenko Chernigiv National Pedagogical University. No. 141, pp. 11-15 (Series: "Pedagogical Sciences"). [in Ukrainian].

2. Bezlyudna, V. V. (2017). Profesiyna pidhotovka maybutnikh uchyteliv inozemnykh mov u vyshchykh pedahohichnykh navchalnyy zaklad Ukrayiny (19482016 rr.): Teoriya i praktyka [Professional training of future foreign languages teachers in higher pedagogical 
educational institutions of Ukraine (1948-2016): theory and practice].Uman: Sochinskiy Publ., 342 p. [in Ukrainian].

3. Bim, I. L. (1989). Navchannya inozemnym movam poshuk novykh shlyakhiv [Learning Foreign Languages - searching new ways]. No. 1. [in Ukrainian].

4. Vyshcha shkola (1978): zbirnyk osnovnykh postanov, nakaziv ta instruktsiy: $v$ 2-kh ch. [High school: a collection of basic decrees, orders and instructions: in 2 parts.] (Ed.).E. I. Voylenko. Moscow. High school. No. 2, 360 p. [in Russian].

5. Myrolyubov, A. A. (2002). Istoriya vitchyznyanoyi metodyky navchannya inozemnym movam [History of the domestic method of teaching foreign languages]. Moskow. STUPENY, YNFRA-M, 448 p. [in Russian].

6. Nikolayeva, S. Y., Petrashchuk, O. P. \& Brazhnyk, N. O. (1996). Stupeneva systema osvity $v$ Ukrayini ta systema navchannya inozemnykh mov [Multilevel system of education in Ukraine and the system of teaching foreign languages]. Kyiv, Lenvit, 90 p. [in Ukrainian].

7. Skurativska, M. O. (2009). Suchasni metody ta tekhnolohiyi vykladannya inozemnykh mov u vishchiy shkoli Ukrayiny [Modern methods and technologies of teaching foreign languages in the prominent school of Ukraine]. Philology and methods of teaching: science-method. Bulletin. pp. 151-164. [in Ukrainian].

8. Sukhomlynskyy, O. V. (2014). Radyanska pedahohika yak ideolohiya: sproba istorychnoyi rekonstruktsiyi [Soviet pedagogy as an ideology: an attempt of historical reconstruction]. Historical and pedagogical almanac. No. 1, pp. 4-24. [in Ukrainian].

9. Ter-Mynasova, S. H. (2004). Mova i mizhkulturna komunikatsiya [Language and intercultural communication]. 2 vol. Moskow. 352 p. [in Russian].

Стаття надійшла до редакції 23.01.2019

UDC 378.1.61

DOI:

Nataliya Tymoshchuk, Ph.D.(Philology), Associate Professor of the Ukrainian and Foreign Languages Department Vinnytsya National Agrarian University

\section{PROFESSIONAL TRAINING OF AGRARIAN SECTOR SPECIALISTS IN THE UK}

The article considers some aspects of higher agrarian education in Great Britain. The UK's higher education system is one of the most complex all over the world. The United Kingdom uses a unitary education system to train specialists of the agrarian sector. The peculiarity of the professional training system in the UK is that curricula and training programs meet the needs of the economy. The close cooperation of entrepreneurs and agricultural education institutions; wide international relations between the institutions of agrarian education; e-learning development; decentralization; flexibility; market orientation and entrepreneurship; professional training of specialists in the agrarian sector through programs of vocational and higher education are the basic characteristics of professional training of agricultural specialists in the United Kingdom.

In addition, UK higher education qualifications are professionally oriented and academic, standardized according to the National Qualifications Framework and the Framework for Higher Educational Qualification. The educational programs of higher agrarian institutions are rather flexible; it increases the quality training of specialists in the agricultural sector. The advantage of British higher agricultural education is its extraordinary flexibility in terms of methods, forms and learning styles. Curriculums provide students with a basic agricultural knowledge. Practical trainings allows students to gain experience at agricultural or industrial enterprise in the agrarian sector. The system of professional training of agrarian specialists allows British universities to develop their own postgraduate training programs. Compliance with the uniform university standards is ensured by the practice of inviting independent examiners. The distance learning plays a significant role in the training of agrarian specialists. training.

Keywords: higher agrarian education in the UK; professional training; agrarian sector; curriculum; distance Ref. 12.

Наталія Тимощук, кандидат філологічних наук, доцент кафедри української та іноземних мов Вінницького національного аграрного університету

\section{ПРОФЕСІЙНА ПІДГОТОВКА ФАХІВЦІВ АГРАРНОЇ ГАЛУЗІ У ВЕЛИКОБРИТАНІЇ}

У статті розглянуто окремі аспекти вищої аграрної освіти Великої Британії, безперечною перевагою якої є ї̈ надзвичайна гнучкість щодо способів, форм, методів і темпів навчання. Автором детерміновано превалюючі тенденції професійної підготовки фахівців аграрної сфери Великої Британії, якій властивий тісний зв 'язок підприємців із закладами аграрної освіти; міжнародне співробітництво; ивидкий розвиток 